\title{
Favipiravir and COVID-19: A Simplified Summary
}

\author{
Authors \\ Morteza Ghasemnejad-Berenji ${ }^{1 \mathbb{D}}$, Sarvin Pashapour ${ }^{2}$
}

\author{
Affiliations \\ 1 Department of Pharmacology and Toxicology, Faculty of \\ Pharmacy, Urmia University of Medical Sciences, Urmia, \\ Iran \\ 2 Department of Pediatrics, Faculty of Medicine, Motahari \\ Hospital, Urmia University of Medical Sciences, Urmia, \\ Iran
}

Key words

antiviral drugs, drug research, clinical trials

received $\quad 16.09 .2020$

accepted 20.10.2020

published online 11.11 .2020

\author{
Bibliography \\ Drug Res 2021; 71: 166-170 \\ DOI 10.1055/a-1296-7935 \\ ISSN 2194-9379
}

(c) 2020. Thieme. All rights reserved.

Georg Thieme Verlag KG, Rüdigerstraße 14, 70469 Stuttgart, Germany

\author{
Correspondence \\ Dr. Morteza Ghasemnejad-Berenji, Assistant Professor \\ Department of Pharmacology and Toxicology, School of \\ Pharmacy, Urmia University of Medical Sciences \\ PO Box: 5715799313 Urmia \\ Iran \\ Tel.: + 98-44-32754996, Fax: +98-44-32754996 \\ morteza.ghasemnejad@yahoo.com; \\ mghasemnejad@alumnus.tums.ac.ir
}

\section{ABSTRACT}

A recent outbreak of coronavirus disease 2019 (COVID-19) caused by the novel coronavirus designated as severe acute respiratory syndrome coronavirus 2 (SARS-CoV-2) started in Wuhan, China, at the end of 2019 and then spread rapidly all over the world. However, there are no specific antiviral therapies for COVID-19, using the agents which approved or in development for other viral infections is one of the potentially quickest ways to find treatment for this new viral infection. Favipiravir is an effective agent that acts as a nucleotide analog that selectively inhibits the viral RNA dependent RNA polymerase or causes lethal mutagenesis upon incorporation into the virus RNA. In view of recent studies and discussion on favipiravir, in this mini review we aimed to summarize the clinical trials studying the efficacy and safety of favipiravir in patients with COVID-19.

\section{Introduction}

At the end of 2019, novel coronavirus pneumonia (NCP) emerged in Wuhan and had spread rapidly. The pathogen was confirmed new coronavirus, which was officially named coronavirus disease-19 (COVID-19) by the World Health Organization (WHO) [1]. The clinical characteristics of COVID-19 include fever, respiratory symptoms, dyspnea, cough and pneumonia [2-5]. Currently, there is no specific antiviral treatment for COVID-19. Therefore, identifying drug treatment options as soon as possible is critical for the response to the COVID-19 outbreak [6]. It has been revealed that SARS-CoV-2 has a genome sequence that is $75-80 \%$ identical to that of SARS-CoV, so, the existing treatment favipiravir for SARS and MERS may be helpful for developing COVID-19 therapeutics [7, 8]. Favipiravir, also known as T-705 was being developed in 2002 as an inhibitor of influenza virus replication [9]. The structures of favipiravir shown in > Fig. 1. Favipiravir was approved for treatment of novel influenza on February 15, 2020 in China [10]. This drug is currently undergoing clinic trials in treating COVID-19. Favipiravir is a type of RNA-dependent RNA polymerase (RdRp) inhibitor. It is converted by host enzymes to T-705- ribofuranosyl 5 '-triphosphate and presumably acts as a nucleotide analog that selectively inhibits the viral RNA dependent RNA polymerase ( $\mathbf{F i g . ~ 2 ) ~ o r ~ c a u s e s ~}$ lethal mutagenesis upon incorporation into the virus RNA without cytotoxicity to mammalian cells [11-15]. Besides influenza virus [16], favipiravir has shown potent antiviral activity against other segmented negative-strand RNA viruses such as arena- and bunyaviruses in vitro and in vivo $[17,18]$. In addition, favipiravir has also demonstrated activity against positive-strand RNA viruses such as noro- and flaviviruses [19, 20]. Therefore, favipiravir may have potential antiviral action on SARS-CoV-2, which is an RNA virus. It has been demonstrated that, as a prodrug, favipiravir effectively inhibits the SARSCoV- 2 infection in Vero E6 cells (ATCC-1586) [21]. On 
February 14, a clinical trial on favipiravir for the treatment of COVID-19 initiated by the Clinical Medical Research Center of the National Infectious Diseases and the Third People's Hospital of Shenzhen achieved promising results. The preliminary results from a total of 80 patients (including the experimental group and the control group) indicated that favipiravir had more potent antiviral action than that of lopinavir/ritonavir. No significant adverse reactions were noted in the favipiravir treatment group, and it had significantly fewer adverse effects than the lopinavir/ritonavir group [7].

\section{Studies of Favipiravir Conducted In Vitro}

Nucleoside analogues in the form of adenine or guanine derivatives target the RNA-dependent RNA polymerase and block viral RNA synthesis in a broad spectrum of RNA viruses, including human coronaviruses. Favipiravir (T-705), a guanine analogue approved for influenza treatment, can effectively inhibit the RNA-dependent

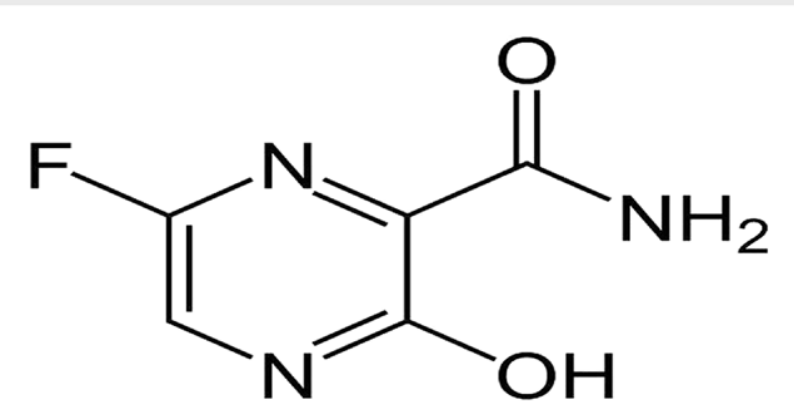

Fig. 1 Chemical structure of favipiravir (T-705) [16].
RNA polymerase of RNA viruses such as influenza, Ebola, yellow fever, chikungunya, norovirus and enterovirus [16], and a recent study reported its activity against 2019-novel corona virus. Chinese researchers who studied the effect of favipiravir in vitro (using Vero E6 cell line infected by SARS-CoV-2) found favipiravir to be effective in reducing viral replication (half-maximal effective concentration $(\mathrm{EC50})=61.88 \mu \mathrm{M}$, half-cytotoxic concentration $(\mathrm{CC50})$ $>400 \mu \mathrm{M}$, selectivity index $(\mathrm{SI})>6.46)[21]$.

\section{Clinical Trials}

At least 18 different clinical trials for SARS-CoV-2 already registered in the Chinese Clinical Trial Registry (ChiCTR) and the International Clinical Trials Registry Platform (WHO ICTRP) propose to use favipiravir in the treatment of COVID-19 ( $\triangleright$ Table 1). For example, patients with 2019-nCoV are being recruited in randomized trials to evaluate the efficacy of favipiravir plus interferon- $\alpha$ (ChiCTR2000029600), favipiravir plus baloxavir marboxil (an approved influenza inhibitor targeting the cap-dependent endonuclease) (ChiCTR2000029544) and favipiravir plus Chloroquine Phosphate (ChiCTR2000030987). In a recent publication, Cai and colleagues found that favipiravir showed significantly better treatment effects on COVID-19 in terms of disease progression and viral clearance indicate. They investigated the effect of favipiravir versus Lopinavir/Ritonavir on the treatment of COVID-19. They reported that favipiravir was independently associated with faster viral clearance and a higher improvement rate in chest imaging. Their findings suggested that favipiravir has significantly better treatment effects on COVID-19 in terms of disease progression and viral clearance, as compared with Lopinavir/Ritonavir [7]. In the recent study Chen and colleagues compare the efficacy and safety of favipiravir and arbidol to treat COVID-19 patients on clinical recovery rate of day

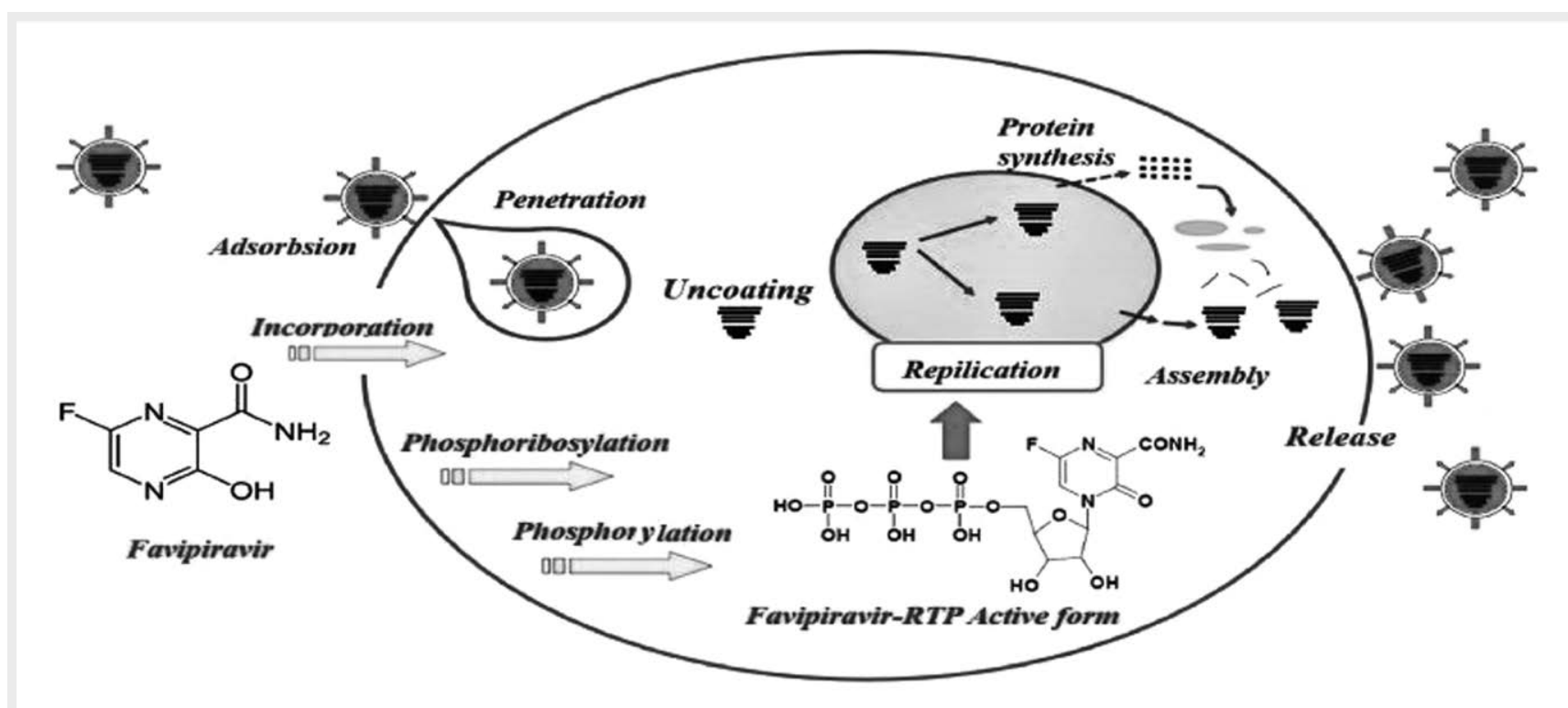

-Fig. 2 Schematic representation of the activation mechanism of favipiravir (Based on Furuta et al. [22]). Favipiravir is incorporated into cells and converted to favipiravir ribofuranosyl phosphates by host cell enzymes. The triphosphate form, favipiravir-RTP, inhibits the influenza viral RNA polymerase activity. 
- Table 1 Characteristics of clinical trials studying the efficacy and safety of favirapir in patients with new coronavirus pneumonia (COVID-19).

\begin{tabular}{|c|c|c|c|c|c|}
\hline ID & Public title & Country & $\begin{array}{l}\text { Recruiting } \\
\text { Status }\end{array}$ & Type & $\begin{array}{l}\text { Registration } \\
\text { time }\end{array}$ \\
\hline ChiCTR2000029544 & $\begin{array}{l}\text { A randomized controlled trial for the efficacy } \\
\text { and safety of Baloxavir Marboxil, Favipiravir } \\
\text { tablets in novel coronavirus pneumonia } \\
\text { (COVID-19) patients who are still positive on } \\
\text { virus detection under the current antiviral } \\
\text { therapy }\end{array}$ & China & Pending & Interventional & $2020 / 02 / 03$ \\
\hline ChiCTR2000029548 & $\begin{array}{l}\text { Randomized, open-label, controlled trial for } \\
\text { evaluating of the efficacy and safety of } \\
\text { Baloxavir Marboxil, Favipiravir, and Lopinavir- } \\
\text { Ritonavir in the treatment of novel coronavirus } \\
\text { pneumonia (COVID-19) patients }\end{array}$ & China & Pending & Interventional & $2020 / 02 / 04$ \\
\hline ChiCTR2000029600 & $\begin{array}{l}\text { Clinical study for safety and efficacy of } \\
\text { Favipiravir in the treatment of novel } \\
\text { coronavirus pneumonia (COVID-19) }\end{array}$ & China & Recruiting & Interventional & $2020 / 02 / 06$ \\
\hline ChiCTR2000030113 & $\begin{array}{l}\text { Randomized controlled trial for safety and } \\
\text { efficacy of Favipiravir in the treatment of novel } \\
\text { coronavirus pneumonia (COVID-19) with } \\
\text { poorly responsive ritonavir/ritonavir }\end{array}$ & China & Recruiting & Interventional & $2020 / 02 / 23$ \\
\hline ChiCTR2000030254 & $\begin{array}{l}\text { the Efficacy and Safety of Favipiravir for novel } \\
\text { coronavirus-infected pneumonia: A } \\
\text { multicenter, randomized, open, positive, } \\
\text { parallel-controlled clinical study }\end{array}$ & China & Completed & Interventional & $2020 / 02 / 26$ \\
\hline ChiCTR2000030894 & $\begin{array}{l}\text { Favipiravir Combined with Tocilizumab in the } \\
\text { Treatment of novel coronavirus pneumonia } \\
\text { (COVID-19) - A Multicenter, Randomized, } \\
\text { Controlled Trial }\end{array}$ & China & Recruiting & Interventional & $2020 / 03 / 16$ \\
\hline ChiCTR2000030987 & $\begin{array}{l}\text { A Randomized Controlled Trial for Favipiravir } \\
\text { Tablets Combine with Chloroquine Phosphate } \\
\text { in the Treatment of Novel Coronavirus } \\
\text { Pneumonia (COVID-19) }\end{array}$ & China & Recruiting & Interventional & $2020 / 03 / 20$ \\
\hline ChiCTR2000033491 & $\begin{array}{l}\text { Oral Favipiravir for Patients with Delayed } \\
\text { SARS-Cov-2 viral RNA Clearance }\end{array}$ & China & Completed & Interventional & $2020 / 06 / 02$ \\
\hline EUCTR2020-001528-32-IT & $\begin{array}{l}\text { Adaptive Randomized trial for therapy of } \\
\text { Corona virus disease } 2019 \text { at home with oral } \\
\text { antivirals }\end{array}$ & Italy & Recruiting & Interventional & $24 / 06 / 2020$ \\
\hline NCT04464408 & $\begin{array}{l}\text { Favipiravir Therapy in Adults with Mild } \\
\text { COVID-19 }\end{array}$ & Saudi Arabia & $\begin{array}{l}\text { Not yet } \\
\text { recruiting }\end{array}$ & Interventional & $28 / 06 / 2020$ \\
\hline JPRN-jRCTs041200025 & $\begin{array}{l}\text { Phase II trial of combination therapy with } \\
\text { favipiravir and corticosteroids for COVID-19 }\end{array}$ & Japan & Recruiting & Interventional & $01 / 07 / 2020$ \\
\hline EUCTR2020-002106-68-GB & $\begin{array}{l}\text { FLARE: Favipiravir } \pm \text { Lopinavir: A RCT of Early } \\
\text { antivirals }\end{array}$ & United Kingdom & ongoing & interventional & $07 / 07 / 2020$ \\
\hline IRCT20150107020592N30 & $\begin{array}{l}\text { Prophylactic Favipiravir for Healthcare Workers } \\
\text { in COVID-19 Pandemic }\end{array}$ & Iran & Recruiting & interventional & $10 / 07 / 2020$ \\
\hline NCT04471662 & $\begin{array}{l}\text { Nelfinavir and Favipiravir Combination in } \\
\text { Newly Diagnosed COVID19 Egyptian Patients }\end{array}$ & Egypt & $\begin{array}{l}\text { Not yet } \\
\text { recruiting }\end{array}$ & Interventional & $13 / 07 / 2020$ \\
\hline NCT04474457 & $\begin{array}{l}\text { Efficacy and Safety of Favipiravir in the } \\
\text { Treatment of COVID-19 Patients Over } 15 \text { Years } \\
\text { of Age }\end{array}$ & Turkey & Recruiting & Observational & $15 / 07 / 2020$ \\
\hline NCT04475991 & $\begin{array}{l}\text { Safety and Efficacy of Maraviroc and/or } \\
\text { Favipiravir vs Currently Used Therapy in Severe } \\
\text { COVID-19 Adults }\end{array}$ & Mexico & $\begin{array}{l}\text { Not yet } \\
\text { recruiting }\end{array}$ & Interventional & $15 / 07 / 2020$ \\
\hline NCT04478448 & $\begin{array}{l}\text { Bioequivalence Study of Favipiravir From } \\
\text { Flupirava } 200 \text { mg Tablet (European Egyptian } \\
\text { Pharmaceutical Industries, Egypt) Versus } \\
\text { Avigan } 200 \text { mg Tablets (Man. by Toyama } \\
\text { Chemical Co., Ltd Japan) }\end{array}$ & Egypt & Recruiting & Interventional & $16 / 07 / 2020$ \\
\hline NCT04501783 & $\begin{array}{l}\text { Study of Efficacy andSafety of TL-FVP-t vs. SOC } \\
\text { in Patients with Mild to Moderate COVID-19 }\end{array}$ & Russian Federation & $\begin{array}{l}\text { Active, not } \\
\text { recruiting }\end{array}$ & Interventional & $05 / 08 / 2020$ \\
\hline
\end{tabular}


7. 120 patients were assigned to favipiravir group (116 assessed) and 120 to arbidol group (120 assessed). In full analysis set (FAS) cohort, for moderate patients with COVID-19, clinical recovery rate of day 7 was $55.86 \%$ in the arbidol group and $71.43 \%$ in the favipiravir group ( $P=0.0199)$. For moderate COVID-19 patients and COVID-19 patients with hypertension and/or diabetes, the latency to fever reduction and cough relief in favipiravir group was significantly shorter than that in arbidol group (both $P<0.001$ ), but there was no statistical difference was observed of auxiliary oxygen therapy or noninvasive mechanical ventilation rate (both $\mathrm{P}>0.05$ ) [23].

\section{Discussion}

The covid-19 has spread rapidly since its recent identification in patients with severe pneumonia in Wuhan, China. Currently, there is no specific antiviral treatment for COVID-19. Therefore, identifying drug treatment options as soon as possible is critical for the response to the COVID-19 outbreak [10,24]. One of the potentially quickest ways to find treatment is to test substances already approved or in development for other viral infections. Favipiravir was discovered by chemical modification of a pyrazine analog initially screened by in vitro anti-influenza virus activity in cells [22]. Favipiravir is a selective and potent inhibitor of influenza viral RNA polymerase [25] and effective against all subtypes and strains of influenza viruses including ones sensitive or resistant to marketed neuraminidase and $\mathrm{M} 2$ inhibitors [26]. Favipiravir demonstrated anti-viral activities against other RNA viruses [27]. These data clearly suggest that favipiravir is a promising drug for the treatment of infections by not only influenza virus but also a wide range of RNA viruses. The research letter, written by a group of Chinese researchers, studied the effect of the influenza antiviral favipiravir in vitro, using Vero E6 cells infected by SARS-CoV-2 at a multiplicity of infection (MOI) of 0.05 demonstrated that favipiravir is effective in reducing viral replication, with half-maximal effective concentration (EC50) $61.88 \mu \mathrm{M}$ [21]. Furthermore favipiravir, has been tested in clinical trials with Covid-19 patients in China. According to an open-label, non-randomized trial the results showed shorter viral clearance time than the control group that received lopinavir/ritonavir [7]. In addition another multicenter, open-labelled clinical trial reported that in moderate COVID-19 patients untreated with antiviral previously, favipiravir can be considered as a preferred treatment because of the higher clinical recovery rate of day 7 and more effectively reduced incidence of fever, cough besides some manageable antiviral-associated adverse effects [23]. However, data of the above studies indicate the efficacy of favipiravir, we need to wait for more clinically valid evidence to confirm the positive value of this antiviral agent for COVID-19 treatment. Furthermore, the adverse reactions of this drug should be kept in mind. In repeatdose toxicity studies involving dogs, rats, and monkeys, notable findings after administration of oral favipiravir included: adverse effects on hematopoietic tissues such as decreased red blood cell ( $R B C$ ) production, and increases in liver function parameters such as aspartate aminotransferase (AST), alkaline phosphatase (ALP), alanine aminotransferase (ALT) and total bilirubin, and increased vacuolization in hepatocytes. Testis toxicity was also noted [28]. Favipiravir is known to be teratogenic; therefore, administration of favipiravir should be avoided in women if pregnancy is confirmed or suspected [25] and toxicity information regarding favipiravir in humans is not readily available so the Ministry of Health, Labor and Welfare granted conditional marketing approval with strict regulations for its production and clinical use [29].

\section{Conclusion}

Favipiravir might be crucial for ensuring an efficient treatment, decrease mortality and allow early discharge in relation to Covid-19. However more clinical studies are urgently needed to evaluate the efficacy and safety of this antiviral nucleoside for COVID-19 treatment.

\section{Author Contributions}

M Ghasemnejad-Berenji; literature review and writing the manuscript writing the original draft of the review article. S. Pashapour: literature review and revising the review article.

\section{Conflict of Interest}

The authors declare that they have no conflict of interest.

\section{References}

[1] Ai J-W et al. Optimizing diagnostic strategy for novel coronavirus pneumonia, a multi-center study in Eastern China. medRxiv 2020; 2020.02.13.20022673

[2] Lai C-C et al. Severe acute respiratory syndrome coronavirus 2 (SARS-CoV-2) and corona virus disease-2019 (COVID-19): The epidemic and the challenges. International Journal of Antimicrobial Agents 2020; 105924

[3] Sohrabi C et al. World Health Organization declares global emergency: A review of the 2019 novel coronavirus (COVID-19). International Journal of Surgery 2020; 76: 71-76

[4] Wang D et al. Clinical characteristics of 138 hospitalized patients with 2019 novel coronavirus-infected pneumonia in Wuhan, China. Jama 2020; 323: 1061-1069

[5] Zhang Jj et al. Clinical characteristics of 140 patients infected by SARS-CoV-2 in Wuhan, China. Allergy 2020; 75: 1730-1741

[6] Yao TT et al. A Systematic Review of Lopinavir Therapy for SARS Coronavirus and MERS Coronavirus-A Possible Reference for Coronavirus Disease-19 Treatment Option. Journal of Medical Virology 2020; 92: 556-561

[7] Cai Q et al. Experimental Treatment with Favipiravir for COVID-19: An Open-Label Control Study. Engineering 2020; https://10.1016/j. eng.2020.03.007. Online ahead of print.

[8] Li G, De Clercq E. Therapeutic options for the 2019 novel coronavirus (2019-nCoV). 2020, Nature Publishing Group

[9] Furuta $Y$ et al. In vitro and in vivo activities of anti-influenza virus compound T-705. Antimicrobial Agents and Chemotherapy 2002; 46: 977-981

[10] Dong L, Hu S, Gao J. Discovering drugs to treat coronavirus disease 2019 (COVID-19). Drug Discoveries \& Therapeutics 2020; 14: 58-60

[11] Baranovich T et al. T-705 (favipiravir) induces lethal mutagenesis in influenza A H1N1 viruses in vitro. Journal of Virology 2013; 87: 3741-3751 
[12] Furuta $Y$ et al. Mechanism of action of T-705 against influenza virus. Antimicrobial Agents and Chemotherapy 2005; 49: 981-986

[13] Jin Z et al. The ambiguous base-pairing and high substrate efficiency of T-705 (favipiravir) ribofuranosyl 5'-triphosphate towards influenza A virus polymerase. PLoS One 2013; 8: e68347

[14] Smee DF et al. Intracellular metabolism of favipiravir (T-705) in uninfected and influenza A (H5N1) virus-infected cells. Journal of Antimicrobial Chemotherapy 2009; 64: 741-746

[15] Vanderlinden E et al. Distinct effects of T-705 (favipiravir) and ribavirin on influenza virus replication and viral RNA synthesis. Antimicrobial Agents and Chemotherapy 2016; 60: 6679-6691

[16] Furuta Y, Komeno T, Nakamura T. Favipiravir (T-705), a broad spectrum inhibitor of viral RNA polymerase. Proceedings of the Japan Academy, Series B 2017; 93: 449-463

[17] Gowen BB et al. In vitro and in vivo activities of T-705 against arenavirus and bunyavirus infections. Antimicrobial Agents and Chemotherapy 2007; 51: 3168-3176

[18] Safronetz D et al. The broad-spectrum antiviral favipiravir protects guinea pigs from lethal Lassa virus infection post-disease onset. Scientific Reports 2015; 5: 14775

[19] Rocha-Pereira J et al. Favipiravir (T-705) inhibits in vitro norovirus replication. Biochemical and Biophysical Research Communications 2012; 424: 777-780

[20] Sidwell RW et al. Efficacy of orally administered T-705 on lethal avian influenza A (H5N1) virus infections in mice. Antimicrobial Agents and Chemotherapy 2007; 51: 845-851
[21] Wang M et al. Remdesivir and chloroquine effectively inhibit the recently emerged novel coronavirus (2019-nCoV) in vitro. Cell Research 2020; 30: 269-271

[22] Furuta $Y$ et al. Favipiravir (T-705), a novel viral RNA polymerase inhibitor. Antiviral Research 2013; 100: 446-454

[23] Chen C et al. Favipiravir versus Arbidol for COVID-19: A Randomized Clinical Trial. medRxiv 2020; Preprint posted March 27, 2020

[24] Lipsitch M, Swerdlow DL, Finelli L Defining the epidemiology of Covid-19-studies needed. New England Journal of Medicine 2020; 382: 1194-1196

[25] Delang L, Abdelnabi R, Neyts J. Favipiravir as a potential countermeasure against neglected and emerging RNA viruses. Antiviral Research 2018; 153: 85-94

[26] Shiraki K, Daikoku T. Favipiravir, an anti-influenza drug against life-threatening RNA virus infections. Pharmacology \& Therapeutics 2020; 107512

[27] Mendenhall M et al. T-705 (favipiravir) inhibition of arenavirus replication in cell culture. Antimicrobial Agents and Chemotherapy 2011; 55: 782-787

[28] Avigan (favipiravir) Review Report. Pharmaceuticals and Medical Devices Agency, 2014

[29] Nagata T et al. Favipiravir: a new medication for the Ebola virus disease pandemic. Disaster Medicine and Public Health Preparedness 2015; 9: 79-81 